\title{
Procalcitonin in liver dysfunction — Dr Jekyll or Mr Hyde?
}

\author{
Ewa Woźnica, Lidia Łysenko \\ Chair and Department of Anaesthesiology and Intensive Care, Wrocław Medical University, Poland
}

\begin{abstract}
Serum procalcitonin (PCT) is a sensitive biomarker used for the diagnosis of infection and sepsis. PCT has also some toxic effects. It is not a proinflammatory stimulus, but may augment the inflammatory processes. High levels of PCT in sepsis may lead to hepatocyte necrosis and, as a result, to liver failure. The pathomechanism of the toxic effect of $\mathrm{PCT}$ is still unknown.

The influence of liver function on PCT levels has not been studied yet. It is not sure whether the liver dysfunction affects the diagnostic and prognostic value of serum PCT levels.

In patients with acute liver failure, the usefulness of PCT-level determination remains controversial. Recent studies have shown a potential diagnostic benefit of PCT as a marker of infection in chronic liver diseases. In both groups there is still no consensus on the optimal cut-off value of PCT levels in order to exclude infection. In patients with liver disease, the serum PCT levels should be interpreted with caution, taking into consideration other factors affecting the PCT threshold.
\end{abstract}

Anaesthesiology Intensive Therapy 2018, vol. 50, no 3, 226-229

Key words: sepsis, procalcitonin, liver dysfunction, hepatocytes

Procalcitonin (PCT) is a precursor of calcitonin, produced by the $C$ cells of the thyroid. In bacterial infections, bacterial toxins (lipopolysaccharides-LPS) and proinflammatory cytokines (TNF-a, IL-1 $\beta$ ) induce the expression of CALC-1 and CTmRNA genes in the neuroendocrine cells of the liver, lungs, intestines, pancreas, brain, and kidneys, as well as adipocytes and peripheral blood cells (monocytes, lymphocytes, granulocytes), which leads to an increase in serum PCT levels [1]. The organs and tissues producing the highest amounts of PCT include the liver, kidneys, ovaries, urinary bladder and adrenal glands [2].

Elevated serum PCT levels are considered an early and sensitive marker of infection and sepsis [3]. PCT is an early marker for differentiating between systemic inflammatory response syndrome (SIRS) and sepsis in critically ill patients [4]. In the healthy population, the level of PCT is low, i.e. $<0.05$ $\mathrm{ng} \mathrm{mL} \mathrm{m}^{-1}$ [5]. At the level of $\leq 0.2 \mathrm{ng} \mathrm{mL}^{-1}$ sepsis may almost certainly be excluded [6]. PCT starts to increase within 2 hours after exposure to a damaging factor, reaching its peak concentration by hour 14 and is positively correlated with the severity of infection [7]. The most significant increases in PCT are observed in bacterial infections and some parasitic infections (e.g. malaria); however, high levels of PCT do not exclude viral infections. In general, the serum levels of PCT are lower in fungal infections, as compared with bacterial infections [8].

Besides infections, elevated serum PCT levels are observed in cases of surgeries, traumas, burns, acute pancreatitis, neuroendocrine tumours, acute kidney injury, acute liver failure and multiple organ dysfunction syndrome (MODS) [9].

The liver is essential for maintaining homeostasis. Liver failure, as a component of MODS complicating sepsis/septic shock, significantly affects the mortality of patients. In sepsis, the liver plays a vital role in cleansing the blood of bacteria and LPS; moreover, it is the source of proinflammatory mediators [10].

Depending on the baseline liver function, sepsis-associated liver dysfunction (SALD) is an acute process or acute-on-chronic liver failure (AoCLF). The prevalence of SALD is difficult to estimate as there is no uniform definition. According to the 2016 Surviving Sepsis Campaign guidelines, the diagnosis of SALD is established based on the serum levels of bilirubin $>2 \mathrm{mg} \mathrm{dL}^{-1}\left(34.2 \mu \mathrm{mol} \mathrm{L}^{-1}\right)$ and clotting disorders with an increase in INR $>1.5$ [11]. How- 
ever, the concentration of bilirubin is not an ideal marker as it does not allow one to differentiate acute liver failure from pre-existing organ dysfunction. It is estimated that the concentration of bilirubin exceeds $2 \mathrm{mg} \mathrm{dL}^{-1}$ within the first 48 hours in $10.9 \%$ of patients newly admitted to the intensive care unit (ICU) [12].

The clinical manifestations of SALD include hypoxic hepatitis, sepsis-induced cholestasis and others [13]. Liver dysfunction may manifest itself as haemorrhagic diathesis associated with impaired synthesis of clotting factors and disorders of consciousness resulting from a defective detoxifying function of the liver. However, hepatic encephalopathy is difficult to diagnose in ICUs due to analgosedation and non-standard determinations of serum ammonia levels.

The impact of liver function on PCT levels has not been fully elucidated and it is not clear whether liver dysfunction affects the usefulness of PCT for the diagnosis of infections.

The aim of the paper was to discuss the current state of knowledge regarding the usefulness of PCT for the diagnosis of infections in patients with various forms of liver dysfunction and to review the literature reports about potentially toxic effects of PCT on the function of hepatocytes.

\section{PCT AS A TOXIC BIOMARKER IMPAIRING THE FUNCTION OF HEPATOCYTES — DR JEKYLL OR MR HYDE?}

There have been some reports demonstrating that PCT, so far considered the gold standard for the diagnosis of sepsis, can be an additional factor enhancing the body's inflammatory response. Experiments in animal models have shown toxic effects of PCT. Although PCT is not a pro-inflammatory factor, it can intensify the inflammatory process [14]. Additionally, impaired migration of neutrophils in sepsis caused by the presence of numerous inflammatory mediators (lipoxins, cytokines, nitric oxide, carbon monoxide) can also be partially triggered by increased serum levels of PCT [15, 16]. PCT enhances the expression of nitric oxide synthase (iNOS), primarily induced by TNF- $\alpha$ and IFN- $\gamma$ in the presence of LPS, thus enhancing, for instance, the vasodilating effects of nitric oxide [17]. Moreover, higher levels of PCT impair the phagocytic and fungicidal activity of neutrophils [18].

$\mathrm{PCT}$, as a factor activating the monocyte chemotaxis towards an infection source, impairs this process in the presence of additional inflammatory factors [19]. Increased levels of PCT in patients with sepsis can weaken the specific resistance of cells by impairing the activation of T lymphocytes and inhibiting the excessively active inflammatory process [20].

PCT is suspected to be another factor impairing the function of hepatocytes. In the in vitro study on the cell line of human hepatocytes, Sauer et al. [21] have demonstrated that PCT directly impairs the function of hepatocytes and exerts cytotoxic effects. Over a period of 72 hours, the hepatocytes were exposed to incremental concentrations of PCT (ranging from 0.01 to $50 \mathrm{ng} \mathrm{mL}^{-1}$ ) or to phosphate-buffered $0.9 \% \mathrm{NaCl}$ as a negative control and acetaminophen as a positive control. Subsequently, their proliferation capacity and metabolic activity, described as the ability to synthesise albumins, as well as the detoxifying function of cytochrome P450 1A2 were evaluated.

PCT affected the proliferation and metabolism of hepatocytes proportionally to each of the concentrations used. The synthesis of albumins was already impaired at $0.01 \mathrm{ng}$ $\mathrm{mL}^{-1}$. Hepatocyte necrosis occurred at $0.25 \mathrm{ng} \mathrm{mL}^{-1}$. The PCT level of $2.5 \mathrm{ng} \mathrm{mL}^{-1}$ significantly impaired the detoxifying function of P450 1A2 and inhibited the proliferation of hepatocytes. The concentration of lactate dehydrogenase (LDH) in the supernatant (the fluid above a sediment) increased proportionally to the concentration of PCT in the solution, starting from $0.25 \mathrm{ng} \mathrm{mL}^{-1}$, due to the lysis of hepatocytes. The biological effect of PCT causing the release of LDH was found comparable with the toxic action of acetaminophen at the PCT level of $2.5 \mathrm{ng} \mathrm{mL}^{-1}$. The levels of $\mathrm{PCT}>50 \mathrm{ng} \mathrm{mL}^{-1}$ affected the proliferation and metabolism of hepatocytes in a similar way as the toxic effects of acetaminophen. The pathomechanism of PCT-induced damage to hepatocytes has not been fully explained and requires further in vivo studies [21].

\section{ACUTE LIVER FAILURE (ALF)}

In Europe, ALF is a rare disease with an incidence rate of 1-8 cases per 1 million inhabitants [22]. In Poland, its incidence rate is not known. The most common causes of ALF include drugs (acetaminophen, isoniazids, sulphonamides, Chinese herbs) and hepatotropic viruses (HBV, HDV, HAV, CSV, HSV, EBV). One of the common causes of ALF in Poland is still Amanita phalloides poisoning [23].

The diagnosis of infection in patients with acute liver failure is controversial as the manifestations of SIRS occur both in infections and ALF. The current state of knowledge and individual reports available in the literature are not sufficient to assess unequivocally the usefulness of PCT as a diagnostic tool for the diagnosis of infection and sepsis in ALF patients.

Sugihara et al. [24], who carried out a study in patients with acute hepatitis, have demonstrated that the serum PCT level in patients with ALF was higher than that in patients without ALF, although infection was not diagnosed in any of these groups. The pathomechanism of an increase in serum PCT levels in these patients is unknown. At least two causes have been implicated. The first one is likely to be an increase in PCT in response to bacterial translocation with subsequent endotoxaemia and SIRS $[24,25]$. The second cause is considered to be a proinflammatory cytokine-induced PCT 
increase. Subsequently, PCT heightens further increases in its concentration as a result of a positive feedback mechanism [26].

Acute alcohol-induced liver damage and acute viral hepatitis underlain by liver cirrhosis or acute parenchymal fibrosis increase the serum level of PCT above $0.5 \mathrm{ng} \mathrm{mL}^{-1}$, irrespective of the co-existence of an infection. In the clinical cases mentioned above, the threshold PCT levels have to be re-validated to be sensitive and specific for the diagnosis of infection in ALF patients [27, 28].

In patients with ALF caused by an overdose of acetaminophen, increased PCT levels are most likely to be associated with an inflammatory response to acute hepatocyte necrosis, which disqualifies PCT as a single marker useful for the diagnosis of infections in this group of patients [29]. In another population of patients with ALF caused by overdose of acetaminophen, Mallet et al. [30] have observed a positive correlation between the occurrence of infection and increased serum concentrations of C-reactive protein (CRP) and leukocytosis. Their results suggest the usefulness of determinations of serum CRP levels in patients with ALF on admission to an ICU.

There are no literature reports regarding the usefulness and causes of PCT increases in ALF caused by Amanita phalloides poisoning.

\section{CHRONIC LIVER FAILURE (CLF)}

Liver cirrhosis is the end stage of many chronic liver diseases. Generalised and long-term liver damage leads to lesions in the hitherto normal structure of the organ. The most common cases of liver cirrhosis in the adult population include: alcoholic liver disease; hepatitis B, C, and D; autoimmune hepatitis; and metabolic diseases [31].

Ascites, which is the most frequent complication of advanced liver cirrhosis, can be complicated by spontaneous bacterial peritonitis (SBP). SBP occurs in $10-30 \%$ of patients with ascites and is the most common type of infection in these patients [31]. Pre-hepatic portal hypertension in liver cirrhosis causes changes in plasma and tissue concentrations (liver, intestines) of pro- and anti-inflammatory cytokines, despite the lack of a co-existing infection. It is one of the causes of chronic inflammations in such patients [32]. PCT can be useful for the early diagnosis of SBP while its serum concentration shows a correlation with WBC in the ascitic fluid. The combined use of serum PCT concentrations with white blood cell and platelet counts can prove useful as a marker of infection in the group of patients with liver cirrhosis [34].

Qu et al. [35] have demonstrated the usefulness of PCT determinations for the diagnosis of infections in patients with chronic liver disease. The authors have observed substantially increased PCT concentrations in serum and increased percentages of neutrophils, irrespective of the severity of liver disease. The PCT concentration was strongly positively correlated with the total bilirubin level (TBL) and poorly positively correlated with the model for end-stage liver disease (MELD) and INR. Their results suggest that the PCT concentration excluding the infection should be determined in relation to TBL. The recent studies in chronic liver diseases have shown the usefulness of serum PCT determinations for the diagnosis of infections. However, there is no consensus on the optimal PCT cut-off point to explicitly exclude infection in such groups of patients [27, 35-37]. A sensitive marker confirming infection in patients with liver cirrhosis is CRP. Moreover, CRP is a predictive factor for suspecting infection in patients without the symptoms of infection [37].

\section{SUMMARY}

High PCT concentrations in sepsis are likely to contribute to hepatocyte necrosis, hence liver damage. Therefore, PCT may be an additional factor overlapping the toxic action of inflammatory response mediators and shock-induced liver ischaemia. The above leads to the development of MODS and dramatic increases in mortality of patients during sepsis/septic shock. The pathogenesis of liver damage caused by high PCT concentrations has not been fully elucidated. To date, only in vitro experimental studies in hepatocyte lines have been performed; further in vivo studies and observations are needed to confirm the above findings.

Determinations of PCT levels in liver diseases are not always a useful tool for the diagnosis of infections, especially in cases of acute liver failure caused by an overdose of acetaminophen. Therefore, the serum concentration of PCT as a marker of infection, should be interpreted with great caution in patients with liver diseases.

\section{ACKNOWLEDGMENTS}

1. Source of funding: none.

2. Conflict of interest: none.

\section{References:}

1. Müller B, White JC, Nylén ES, et al. Ubiquitous expression of the calcitonin-i gene in multiple tissues in response to sepsis. J Clin Endocrinol Metab. 2001; 86(1): 396-404, doi: 10.1210/jcem.86.1.7089, indexed in Pubmed: 11232031.

2. Morgenthaler NG, Struck J, Chancerelle Y, et al. Production of procalcitonin (PCT) in non-thyroidal tissue after LPS injection. Horm Metab Res. 2003; 35(5): 290-295, doi: 10.1055/s-2003-41304, indexed in Pubmed: 12915998.

3. Bouadma L, Luyt CE, Tubach F, et al. PRORATA trial group. Use of procalcitonin to reduce patients' exposure to antibiotics in intensive care units (PRORATA trial): a multicentre randomised controlled trial. Lancet. 2010; 375(9713): 463-474, doi: 10.1016/S0140-6736(09)618791, indexed in Pubmed: 20097417.

4. Meynaar IA, Droog W, Batstra M, et al. In critically ill patients, serum procalcitonin is more useful in differentiating between sepsis and SIRS than CRP, II-6, or LBP. Crit Care Res Pract. 2011; 2011: 594645, doi: 10.1155/2011/594645, indexed in Pubmed: 21687569. 
5. Morgenthaler NG, Struck J, Fischer-Schulz C, et al. Detection of procalcitonin (PCT) in healthy controls and patients with local infection by a sensitive ILMA. Clin Lab. 2002; 48(5-6): 263-270, indexed in Pubmed: 12071576.

6. Maruna P, Nedelníková K, Gürlich R. Physiology and genetics of procalcitonin. Physiol Res. 2000; 49 Suppl 1: S57-S61, indexed in Pubmed: 10984072.

7. Dymicka-Piekarska V, Wasiluk A. Procalcitonin (PCT), contemporary indicator of infection and inflammation. Postępy Higieny i Medycyny Doświadczalnej. 2015; 69: 723-728, doi: 10.5604/17322693.1158796.

8. Kibe S, Adams K, Barlow G. Diagnostic and prognostic biomarkers of sepsis in critical care. J Antimicrob Chemother. 2011; 66 Suppl 2: ii33-ii40, doi: 10.1093/jac/dkq523, indexed in Pubmed: 21398306.

9. Meisner M. Update on procalcitonin measurements. Ann Lab Med. 2014; 34(4): 263-273, doi: 10.3343/alm.2014.34.4.263, indexed in Pubmed: 24982830

10. Chand N, Sanyal AJ. Sepsis-induced cholestasis. Hepatology. 2007; 45(1): 230-241, doi: 10.1002/hep.21480, indexed in Pubmed: 17187426.

11. Rhodes A, Evans LE, Alhazzani W, et al. Surviving sepsis campaign: international guidelines for management of sepsis and septic shock: 2016. Intensive Care Med. 2017; 43(3): 304-377, doi: 10.1007/s00134017-4683-6, indexed in Pubmed: 28101605.

12. Kramer L, Jordan B, Druml W, et al. Austrian Epidemiologic Study on Intensive Care, ASDI Study Group. Incidence and prognosis of early hepatic dysfunction in critically ill patients - a prospective multicenter study. Crit Care Med. 2007; 35(4): 1099-1104, doi: 10.1097/01. CCM.0000259462.97164.A0, indexed in Pubmed: 17334250.

13. Nesseler N, Launey $Y$, Aninat $C$, et al. Clinical review: The liver in sepsis. Crit Care. 2012; 16(5): 235, doi: 10.1186/cc11381, indexed in Pubmed: 23134597.

14. Becker KL, Snider R, Nylen ES. Procalcitonin in sepsis and systemic inflammation: a harmful biomarker and a therapeutic target. Br J Pharmacol. 2010; 159(2): 253-264, doi: 10.1111/j.1476-5381.2009.00433.x, indexed in Pubmed: 20002097.

15. Egger G, Aigner R, Glasner A, et al. Blood polymorphonuclear leukocyte migration as a predictive marker for infections in severe trauma: comparison with various inflammation parameters. Intensive Care Med. 2004; 30(2): 331-334, doi: 10.1007/s00134-003-2111-6, indexed in Pubmed: 14727016.

16. Alves-Filho JC, de Freitas A, Spiller F, et al. The role of neutrophils in severe sepsis. Shock. 2008; 30 Suppl 1: 3-9, doi: 10.1097/ SHK.0b013e3181818466, indexed in Pubmed: 18704017.

17. Hoffmann G, Czechowski M, Schloesser M, et al. Procalcitonin amplifies inducible nitric oxide synthase gene expression and nitric oxide production in vascular smooth muscle cells. Crit Care Med. 2002; 30(9): 2091-2095, doi: 10.1097/01.CCM.0000025215.25664.AD, indexed in Pubmed: 12352046.

18. Pincíková T, Bucová M, Slobodníková L. Influrence of recombinant human procalcitonin on phagocytic and candidacidal ability of polymorphonuclear leukocytes and on killing mechanisms of serum and blood aganist bacteria Staphylococcus aureus and Escherichia coli. Vnitr Lek. 2005; 51(12): 1365-1370, indexed in Pubmed: 16430103.

19. Wiedermann FJ, Kaneider N, Egger P, et al. Migration of human monocytes in response to procalcitonin. Crit Care Med. 2002; 30(5): 1112-1117, indexed in Pubmed: 12006810.

20. Bucova M, Zahorec R, Buc M. Immunomodulatory effect of recombinant human procalcitonin on mitogenic activity of lymphocytes. Eur J Immunol. 2006; 31: 87-93.

21. Sauer $\mathrm{M}, \mathrm{Do} ß \mathrm{~S}$, Ehler J, et al. Procalcitonin impairs liver cell viability and function in vitro: a potential new mechanism of liver dysfunction and failure during sepsis? Biomed Res Int. 2017; 2017: 6130725, doi: 10.1155/2017/6130725, indexed in Pubmed: 28255555.

22. Bernal W, Auzinger G, Dhawan A, et al. Acute liver failure. The Lancet. 2010; 376(9736): 190-201, doi: 10.1016/s0140-6736(10)60274-7.

23. Habior A. Ostra niewydolność wątroby. Postępy Nauk Medycznych. 2014; $27: 24-30$.
24. Sugihara $T$, Koda $M$, Okamoto $T$, et al. Serum procalcitonin in patients with acute liver failure. Yonago Acta Med. 2017; 60(1): 40-46, indexed in Pubmed: 28331420.

25. Mallet M, Tripon S, Thabut $D$, et al. Elevated levels of procalcitonin during acute liver failure are not associated with sepsis or worth outcome. J Hepatol. 2016; 64(2): S308-S309, doi: 10.1016/s0168-8278(16)00407-4.

26. Whang KT, Vath SD, Becker KL, et al. Procalcitonin and proinflammatory cytokine in interactions in sepsis. Shock. 1999; 12(4): 268-273, indexed in Pubmed: 10509628.

27. Elefsiniotis IS, Skounakis M, Vezali E, et al. Clinical significance of serum procalcitonin levels in patients with acute or chronic liver disease. Eur JGastroenterol Hepatol. 2006; 18(5): 525-530, indexed in Pubmed: 16607149.

28. Mallet M, Haq M, Tripon S, et al. Elevated procalcitonin is associated with bacterial infection during acute liver failure only when unrelated to acetaminophen intoxication. Eur J Gastroenterol Hepatol. 2017; 29(7): 811-816, doi: 10.1097/MEG.0000000000000862, indexed in Pubmed: 28272093.

29. Rule JA, Hynan LS, Attar N, et al. Acute liver failure study group. procalcitonin identifies cell injury, not bacterial infection, in acute liver failure. PLoS One. 2015; 10(9): e0138566, doi: 10.1371/journal.pone.0138566, indexed in Pubmed: 26393924.

30. Mallet $M$, Haq $M$, Tripon $S$, et al. Elevated procalcitonin is associated with bacterial infection during acute liver failure only when unrelated to acetaminophen intoxication. Eur J Gastroenterol Hepatol. 2017; 29(7): 811-816, doi: 10.1097/MEG.0000000000000862, indexed in Pubmed: 28272093.

31. Wawrzynowicz-Syczewska M. Marskość wątroby. In: Szczeklik A, Gajewski P. ed. Interna Szczeklika. Mały podręcznik . Medycyna Praktyczna, Kraków 2014/2015 : 623-627.

32. Palma MD, Aller MA, Vara $E$, et al. Portal hypertension produces an evolutive hepato-intestinal pro- and anti-inflammatory response in the rat. Cytokine. 2005; 31(3): 213-226, doi: 10.1016/j.cyto.2005.04.008, indexed in Pubmed: 15950486.

33. Wu H, Chen L, Sun Y, et al. The role of serum procalcitonin and C-reactive protein levels in predicting spontaneous bacterial peritonitis in patients with advanced liver cirrhosis. Pak J Med Sci. 2016; 32(6): 1484-1488, doi: 10.12669/pjms.326.10995, indexed in Pubmed: 28083050.

34. Cai $\mathrm{ZH}$, Fan $\mathrm{CL}$, Zheng JF, et al. Measurement of serum procalcitonin levels for the early diagnosis of spontaneous bacterial peritonitis in patients with decompensated liver cirrhosis. BMC Infect Dis. 2015; 15 : 55, doi: 10.1186/s12879-015-0776-4, indexed in Pubmed: 25887691.

35. Qu J, Feng P, Luo Y, et al. Impact of hepatic function on serum procalcitonin for the diagnosis of bacterial infections in patients with chronic liver disease: a retrospective analysis of 324 cases. Medicine (Baltimore). 2016; 95(30): e4270, doi: 10.1097/MD.0000000000004270, indexed in Pubmed: 27472699.

36. Cekin Y, Cekin AH, Duman A, et al. The role of serum procalcitonin levels in predicting ascitic fluid infection in hospitalized cirrhotic and non-cirrhotic patients. Int J Med Sci. 2013; 10(10): 1367-1374, doi: 10.7150/ ijms.6014, indexed in Pubmed: 23983598.

37. Attar BM, Moore CM, George $\mathrm{M}$, et al. Procalcitonin, and cytokines document a dynamic inflammatory state in non-infected cirrhotic patients with ascites. World J Gastroenterol. 2014; 20(9): 2374-2382, doi: 10.3748/wjg.v20.i9.2374, indexed in Pubmed: 24605035.

\section{Correspondening author:}

Ewa Woźnica

Chair and Department of Anaesthesiology

and Intensive Care, Wrocław Medical University

Borowska 213, 50-556 Wrocław, Poland

e-mail:ewa.anna.woznica@gmail.com

Received: 16.11.2017

Accepted: 30.04 .2018 